\title{
Les Déracinés: Brzozowski and Barrès ${ }^{1}$
}

\author{
Maciej Urbanowski
}

\begin{abstract}
Although the work of Stanisław Brzozowski has been extensively described and discussed, his sketch of Maurice Barrès, published in Głosy wśród nocy (Voices in the Night), has not received much scholarly attention. It was not discussed even in the recent collective volume Stanistaw Brzozowski (ko)repetycje (Stanisław Brzozowski: Private Lessons), devoted largely to Glosy wśród nocy. ${ }^{2}$ Nor has it been mentioned, as a rule, by the most prominent scholars of Brzozowski's works.
\end{abstract}

Is this as it should be? Voices in the Night holds an especially important place in Brzozowski's oeuvre. The author compiled it literally on his deathbed, repeatedly changing its composition and content, yet each time retaining the essay on Barrès, which clearly suggests that he regarded this text as significant. Was the eponymous protagonist equally important to him? Brzozowski mentioned Barrès already in his earlier articles and books, and his attitude towards the French author underwent an evolution. He read him as a spokesman of modernity, a representative of contemporary French thought, and finally - as the author of Les Déracinés (The Uprooted), a novel about which Brzozowski wrote with much regard towards the end of his life.

Let us admit right away that from the present-day perspective Brzozowski's interest in Barrès, and especially the appreciation suggested above, may surprise, raise doubts, or even offend. After all, today scholars consider the French author interesting as a political thinker, and specifically as the originator of modern

1 A Polish version of this article ("Les Déracinés: Stanisław Brzozowski i Maurice Barrès”) was published in my book Prawa strona literatury polskiej [On the right side of Polish literature] (Łomianki: Wydawnictwo LTW, 2015), 39-63 (M. U.).

2 Stanisław Brzozowski - (ko)repetycje, ed. Dorota Kozicka, Joanna Orska, and Krzysztof Uniłowski, vol. 1 (Katowice: FA-art, 2012). 
nationalism of the conservative, integral, organic, and even fascist kind; ${ }^{3}$ or as a representative of "anti-Enlightenment" in European thought, ${ }^{4}$ but he is no longer held in high esteem as a literary figure. One must not forget, however, that among twentieth-century continuators of Barrès, critics and biographers list such acclaimed writers as Mauriac, Montherlant, Drieu la Rochelle, Malraux, Vercors, Aragon or Camus. ${ }^{5}$

Brzozowski's interest in Barrès cannot be surprising if one remembers that in the first decade of the twentieth century the French author was at the peak of his political and literary career, and his writings were widely commented on in France and abroad. ${ }^{6}$ The same was true in Poland, although here the reception of his work was rather restricted and had a specific character. During Brzozowski's lifetime, two of Barrès's novels were published in Polish translation: Wyrwani z gruntu ojczystego (Ripped out of Native Ground), a 1904 rendition of Les Dé-

3 Cf. Robert Soucy, Fascism in France. The Case of Maurice Barrès (Berkeley: University of California Press); David Carroll, French Literary Fascism. Nationalism, AntiSemitism, and the Ideology of Culture (Princeton: Princeton University Press, 1995), 19-41; Zeev Sternhell, Maurice Barrès et le nationalisme français [Maurice Barrès and French nationalism] (Paris: Fayard, 2000); Jacek Bartyzel, "Umierać, ale powoli!" O monarchistycznej i katolickiej kontrrewolucji w krajach romańskich 1815 2000 ["To die, but slowly." Monarchist and Catholic counter-revolution in Romance countries 1815-2000] (Kraków: Arcana, 2002), 453-480; Arkadiusz Barut, Egotyzm, etyka, polityka. Myśl konserwatywna Maurycego Barrèsa [Egotism, ethics, politics. The conservative thought of Maurice Barrès] (Kraków: Arcana, 2009). In the most recent Polish textbook of the history of French literature, the author is discussed in the chapter entitled "Antysemityzm i nacjonalizm" [Antisemitism and nationalism] in less than a page-long section: "Maurice Barrès - nacjonalizm integralny" [Maurice Barrès: integral nationalism], Katarzyna Dybeł, Barbara Marczuk, Jan Prokop, Historia literatury francuskiej [The history of French literature] (Warszawa: PWN, 2005), 334f.

4 Zeev Sternhell, Les anti-Lumières. Une tradition du XVIIIe siècle à la guerre froide [The Anti-Enlightenment Tradition] (Paris: Fayard, 2010).

5 Pierre Boisdeffre, Métamorphose de la littérature. De Barrès à Malraux [Metamorphosis of literature: From Barrès to Malraux] (Paris: Editions Alstatia, 1963), 2390; Yves Chiron, Barrès. Le Prince de la jeunesse [Barrès. The prince of youth] (Paris: Perrin 1986); Sarah Vajda, Maurice Barrès (Paris: Flammarion, 2000).

6 For a discussion of Barrès's influence on Brzozowski's French contemporaries, see: Henri Massis, Barrès et nous. Suivi d'une correspondance inédite (1906-1923) [Barrès and we. With unpublished correspondence (1906-1923)] (Paris: Plon, 1962). 
racinés, ${ }^{7}$ and, published soon afterwards, two (!) translations of $\mathrm{Au}$ service de l'Allemagne (In the Service of Germany). ${ }^{8}$ For the sake of completeness, let us add that a year after Brzozowski's death, the novel Colette Baudoche was published, followed in 1921 by Un Jardin sur l'Oronte (A Garden on the Orontes). ${ }^{9}$ Here ended the history of Polish editions of Barrès, who, as can be seen from this enumeration, did not enjoy particularly great renown among Polish publishers or readers. ${ }^{10}$

Although some of Barrès's novels were available in Poland, the same cannot be said about his essays or diaries; moreover, the published novels included those expressing the writer's nationalistic sympathies, but not his first, decadent works, voicing the "cult of the self," praising "proud egotism, which is to serve the deepening of inner experience and the winning of happiness." "This is interesting, since it is the trilogy Le culte du moi (The Cult of the Self, 1881-1891) that was valued more highly by the few Polish critics who wrote about Barrès before Brzozowski. For example, in his extensive study from 1903, devoted mainly to Barrès's early works, Jan Lorentowicz finds in them a "frenetic hymn to individualism," and calls their author an "enthusiastic sceptic," "ironical dandy," and "first-class master of language." This "elegant juggler of ideas" appealed to the critic more than the later Barrès "of deed with not too original a

7 Maurice Barrès, Wyrwani z gruntu ojczystego, vol. 1-2, trans. J. P. (Warszawa: Drukarnia A. T. Jezierskiego, 1904).

8 Maurice Barrès, Pod pikielhauba, trans. Maria Rakowska (Warszawa: Drukarnia A. T. Jezierskiego, 1906); Maurice Barrès, W ustugach Niemiec, trans. Karol Scipio (Kraków: Spółka Wydawnicza Polska, 1908).

9 Maurice Barrès, Colette Baudoche. Historia młodej dziewczyny z Metzu [Colette Baudoche. A history of a young girl from Metz], trans. Zofia Potocka (Lwów: „Słowo Polskie", 1912); Maurice Barrès, W ogrodzie nad Orontem, trans. Maria Ruszczyńska (Poznań: Eos, 1921).

10 In 1929, Adolf Nowaczyński complained about Tadeusz Boy-Żeleński wanting to translate Proust when "in Polish there are so few translations of, for example, a prose writer such as Barrès" whose novels are "powerful, solid, ideological, arch-Gallic, satirical-political, and for us-pedagogical" (Adolf Nowaczyński, "Do Prusa, nie do Prousta!," [To Prus, not to Proust!] Myśl Narodowa 6 (1929): 83.

11 Antoine Adam et al., Literatura francuska [French literature], ed. Antoine Adam, Georges Lerminier, Éduard Morot-Sir, trans. Joanna Arnold-Ejsmond et al., vol. 2. (Warszawa: PWN, 1980), 380f. 
physiognomy," who "started calling to duties and shaking his fists like any passing street chauvinist.",12

Also telling is Władysław Jabłonowski's remark in his introduction to the Polish edition of Les Déracinés: “In Barrès's views, there is much bias; the theses which he develops are guilty of doctrinarism, at times he overly narrows the notion of homeland to traditional virtues of a particular portion of the whole country, and to the borders of one province [...]."13

Leaving aside for the time being Brzozowski's remarks on Barrès, let us add here that after 1918, the French author was not very widely discussed, and if such discussions did take place, it was usually among writers associated with the political right (understood in broad terms). This is exemplified by Jan Emil Skiwski's 1929 extensive study "Maurice Barrès. Próba charakterystyki twórczości" (Maurice Barrès. An attempt to characterize his works). ${ }^{14}$ The last echo of the Polish reception of Barrès, especially interesting in the context of the present paper, was Andrzej Trzebiński's sketch “Korzenie i kwiaty myśli współczesnej" (The roots and flowers of modern thought), published in German-occupied Warsaw in 1942, in the underground journal Sztuka $i$ Naród (Art and the Nation). Trzebiński's contribution contained a thesis about the wartime "disappointment with the lures of modern thought" and about the necessity, stemming from that disappointment, of returning to four thinkers who overcame the mistakes of contemporary civilisation, namely Bergson, Barrès, Brzozowski, and Heidegger.

This is a surprising constellation of names, especially in that Trzebiński saw all four figures as representatives of "the thought of nationalism." 15 As regards

12 Jan Lorentowicz, "Maurycy Barrès," in: Jan Lorentowicz, Nowa Francya literacka. Portrety $i$ wrażenia [New literary France. Portraits and impressions] (Warszawa: Wł. Okręt, 1911), 216.

13 Władysław Jabłonowski, introduction to Wyrwani z gruntu ojczystego, by Maurice Barrès (Warszawa: Drukarnia A. T. Jezierskiego, 1904), ix.

14 Published in Skiwski's volume of essays Poza wieszczbiarstwem i pedanteria. Żeromski-pisarz i apostot - oraz inne szkice krytyczne [Beyond prophecy and pedantry. Żeromski - writer and apostle — and other critical essays] (Poznań: Księgarnia Akademicka Fiszer i Majewski, 1929), 93-115.

15 Andrzej Trzebiński, "Korzenie i kwiaty myśli współczesnej" [Roots and flowers of contemporary thought], Sztuka i Naród 5 (1942): 1-5, in Andrzej Trzebiński, Aby podnieść różę. Szkice literackie i dramat, ed. Maciej Urbanowski (Warszawa: Fronda, 1999), 50f. Commenting on his remarks, Elżbieta Janicka notes that Trzebiński’s essay gives a "pastoral" and "highly inconclusive" impression of Barrès; see: Elżbieta Janicka, Sztuka czy naród? Monografia pisarska Andrzeja Trzebińskiego [Art or na- 
Barrès and Brzozowski, the critic portrayed the first as "[...] the author of the now legendary novel Les Déracinés, the ideologist of so-called 'regionalism'," and contrasted him with "cosmopolitan European intellect." "Elsewhere in his essay, he evokes Les Déracinés again, arguing approvingly: "The thought of Nationalism fights against the déraciné man, the extra-environmental man, against this whole nineteenth-century nomadism of man without a place in the world. It fights devotedly and bravely."17 Hence the similarity of Brzozowski's thought and that of nationalism so defined. According to Trzebiński, "In Brzozowski's writings, his famous metaphorical definition of Romanticism as a revolt of the flower against its roots, is not only beautiful, but also astonishingly consistent."

\section{Barrès in Brzozowski's Texts}

Yet Brzozowski himself never fully identified with Barrès. He first mentioned the French author in passing in his 1903 discussion of Karol Irzykowski's Patu$b a$ (The Hag). Writing about "weak individuals" (jednostkach słabych), who "struggle to create surrogate ideals for themselves" (usiłują sobie wytworzyć surogaty ideału) and "attempt to make themselves have faith" (starają się wmówić w siebie wiarę), among other figures he mentioned Barrès and his "patriotic activity" (patriotyczną działalność). ${ }^{19}$

Brzozowski's reserve towards the French writer did not change over the next years. This is corroborated by passages in Legenda Młodej Polski (The Legend of Young Poland, 1909) devoted to the author of Colette Baudoche. Here, Brzozowski rejects the Barrèsian vision of relations between the individual and the society, regarding it as deterministic ("[...] society is not a sphere of human responsibility here, it is a fact that one has to accept"), ${ }^{20}$ and deems the French author's anti-Romanticism illusive and superficial. "Did Maurice Barrès really

tion? A literary monograph on Andrzej Trzebiński] (Kraków: Universitas, 2006), 150-154.

16 Trzebiński, "Korzenie i kwiaty myśli współczesnej," 51.

17 Ibid., 52.

18 Ibid., 53.

19 Stanisław Brzozowski, "Cogitationes morosae," Głos 47, 48 (1903), in Brzozowski, Wczesne prace krytyczne, 371. See: “C'est curieux, remarquait Mme Gallant, mon père et mes frères, qui parlaient très bien le patois, n'en tiraient ni vanité ni plaisir. Toi, Henri, tu ne le sais pas, et il te rend heureux et fier!" Maurice Barrès, Le roman de l'énergie nationale. L'appel au soldat (Paris: Bibliothèque Charpentier, 1900), 268.

20 “[...] społeczeństwo nie jest [tu] dziedziną odpowiedzialności ludzkiej, jest faktem, który trzeba przyjąc." Brzozowski, "Cogitationes morosae," $34 \mathrm{f}$. 
get completely rid of romanticism, did he overcome it, was he cured from it [...]" (Czy istotnie tak całkowicie wyzbył się romantyzmu, przezwyciężył go, uleczył się z niego Maurycy Barrès), Brzozowski asked rhetorically, and evoked a scene from L'Appel au soldat (Appeal to a Soldier, 1900), in which the grandmother of one of the protagonists says to him: “[...] it's astonishing, your ancestors lived here and did not bother too much about the dialect, but you make speaking patois a solemnity" (to dziwne, twoi przodkowie mieszkali tu i nie troszczyli się tak bardzo o dialekt, ty zaś robisz z mówienia gwarą jakąś uroczystość). ${ }^{21}$ Brzozowski commented mockingly: "How many times a converted romantic idealized and apotheosized his abandoned home and, having thrown away the rebellious standards, found a dish towel, a napkin or an apron in the trenches of his soul!" (Ileż to już razy idealizował i apoteozował nawrócony romantyk porzucony ład domowy i porzuciwszy buntownicze sztandary, zatykał na okopach swego ducha ścierkę, serwetkę, albo fartuszek!). ${ }^{22}$

Even more pointed remarks can be found in the chapter "Naturalizm, dekadentyzm, symbolism" (Naturalism, Decadence, Symbolism) of Legenda, where Brzozowski speaks of Barrès's "outrageously brutal [...] dilettante soldierdom" (niesłychanie brutalnym [...] dyletanckim zoldactwie). ${ }^{23}$ However, the core of his criticism remained the same: deep within, the Frenchman is a romantic and a determinist:

Pierrot stał się tu pachołkiem oprawcy - konieczności. Dla Barrèsa rzeczywistość pozostaje [...] procesem niezależnym od świadomości; świadomość ma zrezygnować ze swego ja, swego jałowego buntu, wsiąkać w wielki zbiorowy proces, który ją wyłonił. Nie potrzebuję mówić, jak wiele romantyzmu jest w tej Barrèsowskiej walce $\mathrm{z}$ romantyzmem. Dla Barrèsa rzeczywistościami stają się pewne przeciwstawienia świadomości romantycznej. Istnieje dla niego jako rzeczywistość pewien jednolity, zbiorowy proces, wytwarzający świadomość, wystarczy go uznać i zająć w nim miejsce. ${ }^{24}$

In this case Pierrot became the lackey of the assassin — of necessity. For Barrès, reality remains $[\ldots]$ a process independent of consciousness; consciousness is to renounce its ego, its effete revolt [and] sink into the great collective process which brought it forth. It hardly needs saying how much Romanticism there is in Barrès' struggle with Romanticism. For Barrès, what is real stands in opposition to romantic consciousness. Reality for him is a

21 Brzozowski, Legenda Młodej Polski, 31.

22 Ibid., 31.

23 Ibid., 275. Unless indicated otherwise, the emphasis is Brzozowski's.

24 Ibid., $275 f$. 
homogeneous, collective process that creates consciousness; it suffices to recognize it and take one's place in it.

Given the radically anti-German tone of much of Barrès's writing, including the famous novel series Les Bastions de l'Est (Bastions of the East), Brzozowski's juxtaposition of the French author with the Prussians was especially malicious. This is true as well regarding his allusions to the Franco-Prussian war of 1870, whose damaging consequences for French mentality ("un Sedan intellectuel") 25 Barrès was trying to overcome. However, the author of Legenda saw this as a case of imitating what one attempted to overcome:

Pruscy oficerowie w 1870-71 roku, czytając Hartmanna i Schopenhauera, dla odpoczynku notowali swe filozoficzne aforyzmy ostrogami po zwierciadłach, mozaikach, inkrustacjach mebli: jakaś porcelanowa pasterka rozkochała się w pruskim bucie i z tego związku wbrew naturze narodził się patos Barrèsowski. Jest to marzenie rzeczy kosztownych i jedynych, zmiażdżonych przez koła wozu, o tym, jak z kolei one miażdżyć będą, nie marzenie nawet, ale jakieś stopienie się myślą, sercem z gwałcącym procesem. ${ }^{26}$

During 1870-71, Prussian officers, who were reading Hartmann and Schopenhauer, while resting inscribed their philosophical aphorisms with their spurs on mirrors, mosaics, the inlays of furnishings: a certain porcelain shepherdess fell in love with a Prussian boot, and out of this liaison was born, contrary to nature, Barrès's pathos. It is dreaming of costly and unique things, crushed by the wheels of a cart, of how, in turn, they will crush, in fact not really dreaming, but some kind of fusion of thought, the heart with the violent process.

Brzozowski repeated the same observation in his polemic with Wilhelm Mitarski, who compared Barrès to Wyspiański: "W stylu Barrèsa czuje się nieustannie trzask i zgrzyt, głuchy jęk deptanej subtelności"27 (In Barrès' style one senses constantly a sundering and grating, the mute cry of downtrodden subtlety).

Summarising his outrightly critical view, exemplified above, Brzozowski concluded:

25 This is how Sturel refers to it in Les Déracinés: “Avec l'intégrité du territoire à reconstituer, il y a aussi l'intégrité psychologique à sauvegarder." Maurice Barrès, Les Déracinés (Paris: Nelson: undated), 310.

26 Brzozowski, Legenda Młodej Polski, 276.

27 Ibid. 
Nie na zrzeczeniu się samoistności, lecz na samoistnym, świadomym tworzeniu kultury, na tworzeniu form życia, które są w stanie uczynić dziełem swobody dzisiejszy automatyczny i bezwiedny proces zbiorowego istnienia, zasadzać się może jedyne wyzwolenie. ${ }^{28}$

Emancipation can occur not by relinquishing self-sufficient existence, but in the course of the self-sufficient, deliberate creation of culture, in the creation of forms of life able to turn today's automatic and senseless process of collective existence into the work of freedom.

Interestingly, the Polish thinker turned out to be more amicable towards Barrès in Idee (1910, Ideas), including the Frenchman's works among those which exerted a "constant influence" upon him. ${ }^{29}$ In Brzozowski's Pamiętnik (1913, Diary), in turn, written during the last months of his life, Barrès features alongside thinkers such as Nietzsche, Sorel, Maurras, Lafrogue, Pareto, Chesterton, Croce, Seillière, Loisy, Bergson, James, Wells, Kipling and Browning, all highly

28 Ibid., 276.

29 See: “[...] sam w sobie odnajduję wpływ nieustanny Sorela i Proudhona, ale także prac krytycznych Lasserre'a, Seillière'a, pisma Barrèsa, Maurrasa i Chestertona; a byłbym niewdzięcznym, gdybym nie wspomniał Carlyle’a, Carducciego i SainteBeuve'a" (I find in myself the ceaseless influence of Sorel and Proudhon, but likewise of the critical works of Lasserre, Seillière, Barrès's writings, Maurras and Chesterton; I would be ungrateful were I not to mention Carlyle, Carducci and Sainte-Beuve) (Brzozowski, Idee, 352). In a side-remark in his study "Anty-Engels" (Anti-Engels), Brzozowski also disagreed with Karl Lamprecht, who argued that Barrès could not be compared to Nietzsche: "Jest to więcej niż niewątpliwe, jeżeli chodzi o siłę, głębię indywidualności, talentu; jeżeli jednak rozważać to porównanie jako pewien rodzaj oceny dwóch kultur, to jest rzeczą bardzo wątpliwą, czy stanowisko Nietzschego, jego styl, jest dowodem większej dojrzałości, większego wyrobienia kulturalnego środowiska. Barrès reprezentuje punkt widzenia rozpatrywany przez nas pod literą $b$, Nietzsche jest najwybitniejszym i najtragiczniejszym przedstawicielem stanowiska i przeżyć pozostających w związku z punktem widzenia rozpatrywanym pod $a$ " (It is more than doubtless in regard to his force, the depth of his individuality, his talent; if however this comparison is considered as a kind of evaluation of two cultures, then it is doubtful whether Nietzsche's standpoint, his style, is proof of greater maturity, of a greater sophistication of the cultural milieu. Barres represents the point of view we consider under the letter $b$, Nietzsche is the most distinguished and tragic representative of the standpoint and experiences related to the point of view considered under $a$ (Brzozowski, Idee, 330). 
important for the Polish philosopher. ${ }^{30}$ Thus, Barrès, after all, turns out to count among "modern minds, minds expressing the mood and spiritual structure of our times (umysłów nowoczesnych, umysłów wyrażających nastrój i strukturę duchową naszych czasów). ${ }^{31}$

\section{On the Fictional Man: Ground and Blood}

It was the aforementioned sketch from the 1912 Glosy wśród nocy, however, that features Brzozowski's most exhaustive discussion of Barrès. "Maurycy Barrès (Ze studiów nad myślą francuską)" (Maurice Barrès: Studies on French Thought) is a difficult text, exhibiting many typical features of Brzozowski's essay-writing: it is digressive, associative, oscillating between repetition and ellipsis (to recall Michał Głowiński's formulation), lacking clear argumentative sequences on top of which the reader is often left to ponder whether in a particular passage the critic is speaking on his own behalf or reconstructing Barrès's views. ${ }^{32}$ Brzozowski employs characteristic vocabulary, or, to put it in broader terms, imagery, which paraphrases, it seems, the Barrèsian categories of "ground" and "soil," derived from his emblematic organic and medical imagery. ${ }^{33}$ For example, already in the second sentence of his sketch Brzozowski writes: "Dusza jest jak gleba wytwarzająca pewną właściwą sobie roślinność psychologiczną myśli, uczuć, pożądań"34 (The soul is like soil that gives rise to the psychological plant of thinking, feeling, demanding). Further on, he claims:

Pora już byśmy zaczęli się żywić chlebem z własnych pól, by przestała być dla nas nowoczesność czymś, co jest dostępne tylko w nastroju chwili. Jest to rzeczywistość i musimy poznać jej prawa i poznać naturę gruntu i jego uprawy. ${ }^{35}$

30 Brzozowski, Pamiętnik, 38, 89.

31 Ibid., 89.

32 See: Henryk Markiewicz, "Krytyka literacka Brzozowskiego" [Brzozowski's literary criticism], in Od Tarnowskiego do Kotta (Kraków: Universitas, 2010), 143-225; Michał Głowiński, "Wielka parataksa. O budowie dyskursu w Legendzie Młodej Polski" [The great parataxis: Discourse of The Legend of Young Poland], in Ekspresja i empatia. Studia o mtodopolskiej krytyce literackiej (Kraków: Wydawnictwo Literackie, 1997), 265-305.

33 See: Jean-Michel Wittmann, Barrès romancier. Une nosographie de la decadence (Paris: Honoré Champion, 2000).

34 Brzozowski, "Maurycy Barrès," in Głosy wśród nocy, 232.

35 Ibid., 235. 
It is time that we start feeding ourselves with the bread from our own fields, that modernity ceases to be for us something only accessible in the mood of the moment. It is reality and we need to come to know its laws and the nature of its ground and its cultivation.

Another key word of Brzozowski's text is "blood"-again, important in the Barrèsian lexicon, to recall the title of his famous collection of travel writings from Italy, Spain, and Grece: Du sang, de la volupté, de la mort (1893, Of Blood, Voluptuousness and Death), also mentioned by the Polish critic. ${ }^{36}$ In Brzozowski's sketch we read about "the organism of today's thinking" (organizmie myśli dzisiejszej), whose "blood flows in our brains" (krew krąży przez nasze mózgi $)^{37}$, and about nostalgia "producing directly a feverish tremor in our blood" (działającej bezpośrednio w samej krwi naszej gorączkowym dreszczem). ${ }^{38}$ Nor is it easy to define with certainty the genre of Brzozowski's text about Barrès. It oscillates between an essay, a portrait, ${ }^{39}$ and a polemic, approaching the kind of writing which Tomasz Burek once named a critical parable. $^{40}$

It is worth adding that in his letter to Ostap Ortwin of October 1909, Brzozowski mentioned "Maurycy Barrès"-among the pieces left out from the material for Legenda Młodej Polski. ${ }^{41}$ Later he was consistent in including this text in the successive versions of his next planned volume, which was initially meant as the second part of Legenda, entitled Dusze i zagadnienia (Souls and Problems), and which eventually became Głosy wśród nocy. We do not know, however, to what extent the 1912 version differs from that of 1909 .

Finally, also significant is the place of this text in the context of the volume Głosy wśród nocy. It comes after the essay "Kryzys w literaturze rosyjskiej" (The Crisis in Russian Literature) that ended with the warning that,

Niebezpieczeństwo Rosji nie słabnie, lecz wzmaga się i wymaga wzmożonej pracy, wymaga skupienia i podniesienia energii narodowej i tworzenia raz jeszcze nowoczesnej

36 Ibid., 247.

37 Ibid., 234.

38 Ibid., 240.

39 "[...] obchodzi mnie psychologia autora" (I am concerned with the author's psychology), the author writes towards the end. Ibid., 252.

40 Tomasz Burek, introduction to Humor i prawo [Humour and Law], by Stanisław Brzozowski (Warszawa: Czytelnik, 1988), v-xviii.

41 See: Ostap Ortwin, introduction to Brzozowski, Głosy wśród nocy, xii-xiii. 
świadomości; wychowania młodych pokoleń polskich do zwycięskiej biologicznej i ekonomicznej walki w nowoczesnym świecie. ${ }^{42}$

The danger Russia poses is not weakening but growing greater, and it requires increased work, concentration, raising the nation's energy and creating once again a contemporary consciousness; the education of Poland's young generations to a victorious biological and economic struggle in the contemporary world.

And it comes before Brzozowski's discussion of Saint-Simon's memoirs, which in turn begins with the claim that "everything that ever was history concerns us (wszystko, co było kiedykolwiek bądź dziejami jest naszą sprawą) —a truth which "Polish minds" (polskie umysły) ${ }^{43}$ are reluctant to admit.

Thus, clearly apparent here is the context of the "Polish question," or, to be more precise, the problem of "raising the nation's energy." The category of "national energy" recurred in Legenda Młodej Polski; it also constitutes a crucial term in Barrès's lexicon, who, after all, authored Le Roman de l'énergie nationale (The Novel of National Energy). As Robert Soucy observes, "It was one of Barrès favorite themes: reality and energy were inseperable; to know one was to fulfill the other." 44

It is no accident that almost at the very beginning of the essay under analysis, Brzozowski warns against "lyricism" (liryzmem) as "the most insidious temptation within Polish thought" (najniebezpieczniejszą pokusą myśli polskiej). "It is certain that only what speaks out against democracy is worth reading in France today" (To pewna, że tylko to, co występuje przeciw demokracji, jest dzisiaj we Francji godne czytania [...]), ${ }^{46}$ he also notes, specifying another reason for his interest in Barrès, whose criticism of democracy he seemed to embrace. Above all else, however, he saw in Barrès an author whose work reveals "the profound and tragic trait of modernity" (głęboki i tragiczny rys nowoczesności) ${ }^{47}$ and gives insight into "the very essence of contemporary reality" (w samą istotę współczesności), ${ }^{48}$ exposing its "most hidden temptations, the subtlest errors,

42 Stanisław Brzozowski, "Kryzys w literaturze rosyjskiej," in, Głosy wśród nocy, 199.

43 Stanisław Brzozowski, "Z powodu pamiętników Saint-Simona” [On account of SaintSimon's memoirs], in Głosy wśród nocy, 217.

44 Soucy, Fascism in France. The Case of Maurice Barrès, 167.

45 Brzozowski, "Maurycy Barrès," 234.

46 Ibid., 244.

47 Ibid., 247.

48 Ibid., 234. 
and its most instructive downturns" (najtajniejsze pokusy, najsubtelniejsze błędy, najbardziej pouczające upadki). ${ }^{49}$ Brzozowski believed that Barrès's writings

[...] zapewniają mu bardzo poważne stanowisko nie tylko w literaturze francuskiej, lecz wśród umysłów europejskich naszej doby. Są to [bowiem] bardzo cenne przyczynki do świadomości kulturalnej, książki niezbędne dla każdego, kto chce zapoznać się z nowoczesnością jako stwarzaniem konkretnego życia. ${ }^{50}$

[...] ensure that he will have a very important status not only in French literature, but likewise among European minds of our day. For they are very valuable contributions to the cultural consciousness, indispensable for anyone who wants to come to know modernity as the creation of concrete life.

Barrès's evolution reveals fundamental problems of the modern man who, having at first taken relish in his "self" and experienced "the sense of autonomous creativity" (poczucia samowiednego stwarzania), ${ }^{51}$ comes to doubt the self-sufficiency of the self, and asks with uncertainty "what in my psyche truly comes forth from me, and what is the product of accidental, disoriented actions?" (co w mojej psychice wyrasta naprawdę ze mnie, a co jest dziełem przypadkowych, dezorientujących działań). ${ }^{52}$

In contrast to Lorentowicz or Jabłoński, both quoted above, the author of Glosy wśród nocy had more reservations about Barrès's "early" or "transitional" texts. Brzozowski saw in them a gesture typical of the intelligentsia, namely breaking with life in its particularity, and "a critical nostalgia for unknown forms of existence sensed across the entire span of history" (krytyczną tęsknotę dla form istnienia nieznanych, przeczuwanych na całym przestworzu dziejów).$^{53}$ In his description of such longing, Brzozowski refers to the imagery of illness, ${ }^{54}$ as he believes that this kind of attitude is something "poisonous." It assumes an external, as if actor-like approach to reality and oneself; it means recreating the world instead of creating it. What matters for this attitude are aesthetic rather than ethical choices, namely "how will I manage to make of this life something

49 Ibid., 234f.

50 Ibid., 247.

51 Ibid., 247.

52 Ibid., 253.

53 Ibid., 238.

54 Cf. "trawiący duszę organ nostalgii" (the organ of nostalgia besetting the soul), "subtelna trucizna" (subtle poison), "tajemna gorączka" (mysterious fever). Ibid., 238, 237. 
that will suit my taste" (w jaki sposób zdołam z życia uczynić coś [...] co mi przypadnie do smaku). ${ }^{55}$

For Brzozowski, this is what the early Barrès is like; he is a man who, "when he is something regards it from without, as if he only seemed to be so" (gdy jest czymś, patrzy na to z zewnątrz, jakby wydawał się tylko), ${ }^{56}$ and who took the recreation of somebody else's (alien) states of mind to a certain extreme. As Brzozowski sarcastically puts it,

Poszukiwał [on bowiem] ostatecznie indywidualizującego dreszczu; właśnie tak całkowitego skomplikowania, by obca dusza stała się toksyną, weszła w krew, zaraziła swą gorączką i potem, tą gorączką, tym wykrzywieniem, zwężeniem świata aż do granic czapki Hiszpana, dajmy na to, z XVI wieku: iść w nasz czas i chwytać na gorącym uczynku paradoksalne odbicie. $^{57}$

He was searching for the ultimate individualizing shudder; complication on such a complete scale that the alien soul becomes a toxin, enters the blood, infects it with its fever and sweat, this fever, this contortion, this narrowing of the world to the outer limits of a Spaniard's hat of, say, the sixteenth century: to march in our own time and to catch the paradoxical reflection red-handed.

On the other hand, though, Brzozowski believed that the surplus of self-awareness accompanying such imitations makes Barrès's efforts incomplete, and thus feeble when compared to Bourget's or Pater's, with whom the Polish critic contrasted him. The author of Un amateur d'âmes (An Amateur of Souls):

[...] nieustannie pamięta, że to chce wywołać w sobie, wytworzyć tę lub inną psychikę i ta umyślność przesłania mu samo wywołanie; nie może poprzestać on na ziszczeniu. Być może dlatego właśnie, że nie jest, nie bywa ono nigdy zupełne, umie on wydobyć zawsze co najwyżej pewne momenty tylko jakiegoś stanu duszy, i to te, które leżą na pograniczu krwi i umysłu: sama krew działa słabo mimo toksyny, być może dzięki temu, że i nie zatruta, nie jest ona bogata. ${ }^{58}$

[...] he remembers constantly that he wants to invoke this in himself, to create this or that psyche, and this intention only conceals the very invocation; he cannot rest content with fulfillment. Perhaps because it is not, can never be complete, at most he knows how to

55 Ibid., $246 f$.

56 Ibid., 237.

57 Ibid., 240.

58 Ibid., 241. 
extract certain moments of only some state of the soul, and only those lying at the border separating blood and the mind: despite the toxins the blood acts ineffectively, perhaps thanks to not being infected it is not rich.

Finally - but still with regard to the early Barrès-Brzozowski sees here "a historical psychic diletantism and an abstract point of view of the pure will to unconditional action" (dyletantyzm historyczno-psychiczny i abstrakcyjny punkt widzenia czystej woli bezwzględnego czynu), ${ }^{59}$ whose patrons would be two "educators of careerists and the déclassés" (wychowawcy karierowiczów i zdeklasowanych): Ignatius of Loyola and Napoleon Bonaparte. Indeed, both were Barrès's masters: Loyola in the period of the "cult of the self," and Napoleon practically throughout his life. Especially telling here is the famous, oftdiscussed chapter eight of Les Déracinés. The seven young protagonists of the novel, "ripped out of native ground," gather at Napoleon's grave. As the narrator remarks,

Le tombeau de l'Empereur, pour des Français de vingt ans, ce n'est point le lieu de la paix, le philosophique fossé où un pauvre corps qui s'est tant agité se défait; c'est le carrefour de toutes les énergies qu'on nomme audace, volonté, appétit. [...] On n'entend pas ici le silence des morts, mais une rumeur héroïque; ce puit sous le dôme, c'est le clairon épique où tournoie le souffle dont toute la jeunesse a le poil hérissé. ${ }^{60}$

This is how Sturel and his Lorrainian friends feel. For them, Napoleon is "un professeur d'énergie" and "un excitateur de l'âme"; someone who has "puissance de multiplier l'énergie" and "une vertu de lui émanera encore pour dégager les individus et les peuples d'un bon sens qui parfois sent la mort et pour les élever à propos jusqu'à ne pas craindre l'absurde." ${ }^{\text {,61 }}$

Brzozowski, who does not directly refer to this scene, gives a completely different, radically critical image of Napoleon. He disagrees not only with Barrès's cult of the "master of energy," but also with the closely related "caesarism," i.e., the faith in a strong individual who is able to "self-knowingly" direct the course of history. For Brzozowski, Napoleon was a troublemaker who, "being immanently alien in the very society over which he had gained power" (wewnętrznie obcy temu społeczeństwu, którym zawładną), ${ }^{62}$ could "utilize France, cut into interior knots, injure its organ [...] as no one else could have done who under-

59 Ibid., 242.

60 Barrès, Les Déracinés, $210 \mathrm{f}$.

61 Ibid., 215.

62 Brzozowski, "Maurycy Barrès," 245. 
stood and loved this society" ([...] posługiwać się Francją, rozcinać jej wewnętrzne węzły, kaleczyć jej organizm [...], jak nie mógłby czynić tego żaden człowiek pojmujący i kochający to społeczeństwo). ${ }^{63}$ Consequently, Brzozowski sees Napoleon rather as a model for "attending to an easy, superficial relation to life" ([...] do pielęgnowania łatwego, powierzchownego stosunku do życia), ${ }^{64}$ who represented the attitude of "arbitrary romantic individualism" (romantycznego indywidualizmu arbitralnego). ${ }^{65}$

Therefore, Brzozowski will take the most interest in the "late" Barrès, who discovers that "consciousness is born in connection with life" (świadomość rodzi się w związku z życiem) and that it is always an awareness "of just this concrete, specifically determined life" (takiego a takiego właśnie, konkretnego, ściśle określonego życia), ${ }^{66}$ and hence-let us be clear — the national life. "Already the fact that one is French is mere chance, but that one is from the Lorraine and born in Nancy needs to be recalled without delay" (Już to, że się jest Francuzem jest przypadkiem ale o tym, że się jest Lotaryńczykiem urodzonym w Nancy, należy jak najspieszniej przypomnieć) ${ }^{67}$ — Brzozowski recapitulates ironically the standpoint of "the professors of philosophy, scholars, intellectuals" (profesorów filozofii, uczonych, intelektualistów), thus clearly referring to Barrès's biography and to Les Déracinés. He also agrees with the French author that the beliefs of intellectuals are "horrible errors" (potwornymi błędami), ${ }^{68}$ and he deems them characteristic of democracy:

Dziś to jest fikcja demokratyczna - twierdził - fikcja, opierająca się na pojęciu, że oddarty od pracy, wyrwany ze swego środowiska człowiek niezależnie od tego, jaką rolę spełnia w życiu, stwarza je wolą swą i myślą. Ten fikcyjny człowiek ma swój fikcyjny świat: świat,

63 Ibid., 246.

64 Ibid.

65 Commenting on this problem, Stefan Kołaczkowski explained: "The individual does not impose ideas which he draws from his tradition or background, nor those which arise from the essence of his personality, but rather those which he has reached from the outside, whether because they sparked his imagination, or through the despotism of his ambitions or a whim, or through the desire to stifle his inner weakness by imposing a form on himself." Stefan Kołaczkowski, "Stanisław Brzozowski," in Pisma wybrane. Tom I. Portrety i zarysy literackie, ed. Stanisław Pigoń (Warszawa: Państwowy Instytut Wydawniczy, 1968), 186.

66 Brzozowski, "Maurycy Barrès,” 247.

67 Ibid., 249.

68 Ibid., 249. 
którego charakter polega na tym, aby mógł być zawsze całkowicie scharakteryzowany w terminach dostępnych każdemu wyborcy. ${ }^{69}$

Today it has become a democratic fiction, a fiction based on the idea that torn from his work, ripped out of his environement a man, regardless of his role in life, creates it with his will and thinking. This fictional man has his fictional world: a world which is such that it can at every moment be characterized in terms accessible to every voter.

Like Barrès, Brzozowski contrasted the fictional man, "ripped out of his environment," with the "localised" man, connected to his country:

Można na pewno twierdzić, że sam proces powstawania konkretnej woli tworzy zindywidualizowane, konkretnie zabarwione życie umysłowe i że myśl działa tu najsilniej, jeżeli jest zrośnięta $\mathrm{z}$ lokalnymi wyobrażeniami, doświadczeniami osobistymi.

Organem pracy jest życie całego kraju, zlokalizowane, związane z ziemią rodziną, z bezpośrednimi pamiątkami: konkretne, zlokalizowane życie umysłowe, przekazywane $\mathrm{w}$ rodzinie obyczaje, wypróbowane metody tworzenia woli. ${ }^{70}$

It can certainly be affirmed that the very process, in which the concrete will emerge, creates an individualized, concretely tinged life of the mind, and that thinking is most effective when it is fused with local representations and personal experiences.

The organ of labor is the life of a country as a whole, it is local, tied to the family's land, to direct heirlooms: the concrete local life of the mind, customs transmitted within the family, tried and tested methods of constituting the will.

This is why Brzozowski shared the Barrèsian critique, expressed in Les Déracinés, of the modern educational system which "at every level strives to treat the

69 Ibid., 251. Brzozowski probably developed a distaste for democracy, a system which he could not have known well in practice, by reading Sorel, Maurras and Barrès, see: Bronisław Baczko, "Absolut moralny i faktyczność istnienia (Brzozowski w kręgu antropologii Marksa)" [The moral absolute and factual existence (Brzozowski in the context of Marx's anthropology)], in Wokót myśli Stanisława Brzozowskiego, ed. Andrzej Walicki and Roman Zimand (Kraków: Wydawnictwo Literackie, 1974), 172. About the relations between Barrès and Maurras and their views on democracy: Michael Curtis, Three Against the Third Republic. Sorel, Barrès, and Maurras (Princeton: Princeton University Press, 1959); François Huguenin, L'Action Française. Une historie intellectuelle [Action Française. An intellectual history] (Paris: Perrin, 2011), 63-66.

70 Brzozowski, “Maurycy Barrès,” 250. 
child as an abstract entity lacking a determinate past and a probable future" (na wszystkich swoich szczeblach dąży [...] do tego, aby traktować dziecko jako istotę abstrakcyjną bez określonej przeszłości i prawdopodobnej przyszłości) and in this way produces people who "know nothing about their country, know nothing of its workings, its beliefs" (nie wiedzą nic o swoim kraju, nie wiedzą nic, jak on pracuje, w co wierzy). ${ }^{71}$ He also considered "exceedingly true" (niezmiernie słuszne) the postulates of administrative decentralisation, regionalism as the basis of the life of a nation, and also the critique of "the frivolous selfdeception of today's official France" (lekkomyślnej obłudy dzisiejszej Francji oficjalnej). $^{72}$

Notwithstanding that, Brzozowski remained strongly and consistently opposed to Barrès's determinism. He rejected not so much the very claim that "our soul is created by the deceased who preceded us on our ground, our soul is created so that we can pull farther, continue their labor" (dusza nasza stworzona jest przez umarłych, którzy poprzedzili nas na naszej ziemi, dusza nasza stworzona jest do tego, byśmy snuli dalej, ciągnęli ich dzieło), ${ }^{73}$ but rather-I believe-its conservative or even reactionary interpretation, topped with arty egotism. ${ }^{74}$ Brzozowski underscores that

Nie znalazło się $w$ Barrèsie sity zdolnej przezwyciężyć izolację intelektualna, zerwanie ciagłości z życiem, charakteryzujące świadomość kulturalna, zabrakło mu tej siły, która napływa do myśli strugą gorącej krwi i dlatego do swojej Francji doszedł on zewnętrznym procesem, przez wyobraźnię i zżył się nią tylko o tyle, o ile da się ona pomyśleć en bloc, i o ile en bloc współczuć z nią można. Jest to [więc] pisarz nie wzrostu życia, lecz zachowania narodowego. Nie wie on, jak życie rośnie: może on myśleć i mówić o życiu już gotowym. $^{75}$

There were no forces within Barrès able to overcome [his] intellectual isolation, to break the continuity of a life characterized by a cultural consciousness, he lacked the power which flows into the mind like a warm bloodstream, which is why he attained his France by an external process, in his imagination, and he achieved vital contact with it only inso-

71 Ibid., 252.

72 Ibid., 254.

73 Ibid..

74 Concluding his sketch, Brzozowski also quotes Nero's qualis artifex pereo-words which Barrès planned to use as the title of what became Le jardin de Bérénice (The Garden of Berenice, 1891), the last part of the trilogy Le culte du moi-thus, I believe, pointing towards the "egotism" inscribed in the French author's work.

75 Ibid., 255. 
far as it can be conceived en bloc and to the degree that it is possible to empathize with it en bloc. He is [thus] a writer not at the height of life, but restricted to a nation's behavior. He knows not how life grows: he can think and speak only of already determinate life.

What Brzozowski has in mind is an attitude towards life which puts emphasis not on "recovering one's own boundaries" (odnajdywanie własnych granic) of that which is national (Brzozowski believed that this was the case with Barrès), but rather on their "ceaseless widening" (nieustanne rozszerzanie), on the creation of "ever newer, ever more distant determinants, that is, ever newer contexts of nature's elements subjected to human will (tworzenie coraz nowych, coraz odleglejszych determinizmów, to jest coraz nowych zakresów żywiołu poddanych ludzkiej woli). ${ }^{76}$ Thus, Brzozowski's answer to the Barrèsian defense of national "dignity" is the national "strength"; he claims - clearly with his own readers in mind - that "not traditionalism but concrete creativity, creation of life across its entire stretch is the law of a nation's expansion" (nie tradycjonalizm, lecz konkretna twórczość, lecz tworzenie życia cała powierzchna jest prawem narodowego rozrostu). ${ }^{77}$

For Brzozowski, then, his encounter with Barrès's work became an opportunity to mark points of juncture and disjuncture with the then rising modern nationalism. What is interesting, though, is that Brzozowski did not use terms such as "nationalism" or "national socialism," which were coined by Barrès. Nor did he mention at all the problems which were the focus of attention or even outrage of the French author's readers: his racism, chauvinism or anti-Semitism. Instead, Brzozowski regarded as significant and relevant the Barrèsian attempts at overcoming the intelligentsia's detachment from "life" and "nation," and especially his warnings against the "abstract" and "fictional" Cartesian subject, coupled to a defence of the "concrete" subject, "rooted" as Barrès would say, or "localized" in Brzozowski's terms. ${ }^{79}$

This criticism was in line with Brzozowski's search for sources of national strength and energy, undertaken especially in his last works. Here, the Polish writer resembled Barrès in that he, too, diagnosed and criticized his nation's powerlessness, weakness, and decadence. What turned out to be a point of con-

76 Ibid., 256.

77 Ibid..

78 Barut, Egotyzm, 16.

79 See: Bohdan Cywiński, "Narodowe i ludzkie w myśli Stanisława Brzozowskiego," [The national and the human in Stanisław Brzozowski's thought] In Wokót myśli Stanistawa Brzozowskiego, ed. Andrzej Walicki and Roman Zimand (Kraków: Wydawnictwo Literackie, 1974), 275. 
tention, however, was their approach to tradition and work, as well as to "foreignness." Barrès's vision of the nation was far more exclusive than Brzozowski's, even though both writers had behind them the crucial experience of living in the borderlands. After all, each grew up at a crossroads of nations: the Frenchman in the French-German borderland, the Pole in the Polish-Ukrainian-Jewish-Russian melting pot. And yet the narrator of Les Déracinés notes:

S'il est constant qu'un esprit vigoureux, bien assuré de ses assises, peut se hausser de son étroite patrie, de son milieu et de sa race, pour atteindre à d'autres civilizations, on n'a constaté chez personne l'énergie de faire de l'unité avec des elements dissemblables. ${ }^{80}$

This claim is significantly illustrated by the story of François Sturel's affair with the Armenian girl Astiné, who in Barrès's novel represents "un principe qui n'était de sa nature," i.e., "un précipité de mort." 81 The "Asian" mistress tears the protagonist away from his native land, from "intérêts de la vie française.,"82 Barrès gives a similar treatment to French-German relations. Suffice it to recall Colette Baudoche, a novel of which Brzozowski thought highly. ${ }^{83}$ Its eponymous protagonist refuses to marry a young German professor for the sake of protecting her French soul ("ce n'est pas une question personnelle, mais une question française"). ${ }^{84}$ From this perspective, these works can be contrasted with Brzozowski's Płomienie (Flames, 1908) or Dębina (Oakwood, 1911), which tell about their protagonists' tearing free of their nation, but here, this tearing free of the native land has a much more ambivalent nature. In his commentary to Plomienie, Brzozowski claims:

[...] usiłowałem przedstawić, że brak twórczej świadomości narodowej prowadzi od odrywania się jednostek samoistniejszych od narodowej wspólności, do widzenia życia w abstrakcyjnych, upraszczających dogmatach, do niemożności odnalezienia związku z narodem bez zrzeczenia się własnej swobody. Przedstawiłem dzieje Kaniowskiego nie jako błąd, lecz jako cenny, dodatni w danych stosunkach proces myślowy [...]. ${ }^{85}$

80 Barrès, Les Déracinés, 117.

81 Ibid., 116.

82 Ibid., 115.

83 Brzozowski, "Maurycy Barrès," 255.

84 Maurice Barrès, Colette Baudoche. Histoire d'une jeune fille de Metz (Paris: Librairie Félix Juven, 1909), 254.

85 Brzozowski, Legenda Młodej Polski, 443. 
[...] I struggled to show how the absence of creative consciousness leads from more selfsufficient individuals severing their ties with the nation's community to looking at life with abtract, simplistic dogmas, to the impossibility of recovering a connection with the nation without forsaking one's own freedom. I set forth Kaniowski's history not as an error, but, in the given circumstances, as a valuable, positive intellectual process.

Finally, the nation is for Barrès "la terre et les morts," and hence the special significance of the symbolic imagery of the grave, the cemetery, or the funeral in his works. This is exemplified by the famous description of Victor Hugo's funeral in Les Déracinés. ${ }^{86}$ Brzozowski's vision of what a nation is was much more dynamic. In the second edition of Legenda Młodej Polski, he wrote about it in very vivid terms, at the same time leaving no illusions:

Barrès o całym życiu narodowym myśli w kategoriach higieny osobistej. Jego powieści rozpatrują naród raczej jako pewien gatunek automatycznie utrzymującego się zakładu hydroterapeutycznego, a nie zaś jako wielki walczący ze światem otaczającym o samoistność swą i ciągłość organizm. Dość postawić Barrèsa obok takiego nacjonalisty jak Dostojewski lub nawet takiego jak Kipling. Nacjonalizm Barrèsa to przyrząd ortopedyczny, nacjonalizm Kiplinga to natura. ${ }^{87}$

Barrès conceives a nation's entire life in the categories of personal hygiene. His novels look upon the nation rather as a certain kind of automatically self-regulating hydrotherapeutic plant, and not as a mighty organism waging a struggle with the surrounding world in order to achieve self-sufficiency and continuity. It suffices to juxtapose Barrès with a nationalist such as Dostoevsky or even Kipling. Barrès's nationalism is an orthopedic instrument, Kipling's nationalism is nature itself.

Thus, the milieu of French modern nationalism turned out too conservative, too narrow for Brzozowski, and thus too feeble to be able to enhance national en-

86 At the funeral, Hugo Sturel “a distingué la grande source dont sa vie n'est qu'un petit flot. Entraîné parmi ses ondes humaines dans le sillage du genie, il s'est aperçu que leur bon ordre et leur honneur ne lui étaient pas de choses indifférentes, extérieures, et qu'en les supprimant on eût, ce lundi 31 mai, anéanti son âme même. Une circonstance si belle et si rare, qui faisait évidente l'unité de ce pullulement de Français, lui permit encore de saisir d'autres lois: dans ce cortège, chacun maintenait une discipline, en exigeait une, parce que c'était l'intérêt de chacun." Barrès, Les Déracinés, 448.

87 Brzozowski, Legenda Młodej Polski, 350. 
ergy. What he found more appealing was the imperial model of British nationalism of Kipling's variety, i.e., expansive and conquest-oriented.

\section{The “Uprooting"}

In this light, Brzozowski's opinion of Les Déracinés, expressed in the aforementioned essay Kryzys w literaturze rosyjskiej, may seem surprising or even puzzling. What he did there was to compare Thomas Mann's Buddenbrooks with Barrès's novel, deeming them both as "from the point of view of philosophy and society the most profound novel of recent times" (najgłębszą z punktu widzenia myśli fillozoficznej i społecznej koncepcję powieściową ostatnich czasów). ${ }^{88}$

Marta Wyka argues with reference to this statement that Brzozowski saw in Buddenbrooks a work that "describes the crumbling foundations of nineteenthcentury Europe." Tomasz Burek, in turn, points to the theme which would resonate with Poles, namely the fall of a family and "the exhaustion of practical capacities of a given [bourgeois, M. U.] kind of life." ${ }^{, 89}$ But what was it in Barrès's novel that so interested Brzozowski?

Let us recall that it was published in 1897 as the first volume of the trilogy entitled Le Roman de l'énergie nationale, and enjoyed tremendous success, winning Barrès the status of a classic of French fiction. ${ }^{90}$ Józef Heistein, a Polish historian of French literature, not long ago still described Les Déracinés as a masterpiece, and at the same time a "bible of nationalism." wrote in the 1930s about the entire trilogy that "[...] these theses put into fiction do not lack in artificiality or bad faith; nevertheless, the books which contain

88 Brzozowski, "Kryzys w literaturze rosyjskiej," 179; however, he made the proviso: “jeśli naturalnie pozostawić na stronie powieść angielską" (if of course one leaves aside the English novel). Let us add that in the first version of "Kilka uwag o stanie ogólnym literatury europejskiej i o zadaniach krytyki literackiej” (Some Remarks about the General Situation of European Literature and the Tasks of Literary Criticism), Brzozowski included Les Déracinés among the books "that can stimulate thought about the issues raised here" (które mogą przyczynić się do rozbudzenia umysłu dla zagadnień tu poruszanych). Głosy wśród nocy, 75.

89 Marta Wyka, Czytanie Brzozowskiego [Reading Brzozowski] (Kraków: Universitas, 2012), 346; Tomasz Burek, Dalej aktualne [Still relevant] (Warszawa: Czytelnik 1973), 70.

90 Chiron, Barrès, 161.

91 Józef Heistein, Historia literatury francuskiej: od początków do czasów najnowszych [The history of French literature: from the beginnings to the present times] (Wrocław: Zakład Narodowy im. Ossolińskich, 1987), 503. 
them are among Barrès's liveliest works, and have provided the French intelligentsia with topics for discussion for thirty years." "92 Louis Aragon saw in Les Déracinés the first modern political novel in France, and even the point of departure of the novelistic avant-garde. ${ }^{93}$ Pierre Boisdeffre considered Barrès's text to be one of the greatest books of the last quarter of the nineteenth century; he wrote about its great success at the beginning of the twentieth century, and deemed it "the only real novel" of the French writer. ${ }^{94}$

It should be added that Les Déracinés was one of the most influential novels of the twentieth century. The "uprooting" (déracinement) present in the title, as well as the closely related "rootedness" (enracinement), was to play an enormous role throughout the whole century. This was pointed out by, e.g., Andrzej Mencwel in his recent book on Brzozowski. Mencwel notes, first, that this notion was popular with conservatives in the twentieth century and, second, that in order to establish what it meant back then, "one would need to write a thorough study, almost amounting to a history of mid-twentieth-century literature." 95 The theme recurred in the works of many eminent authors, from Przybyszewski and Chesterton to Márai or Tolkien. To Mencwel's long list of names we should certainly add Simone Weil and her study L'Enracinement (1943, The Need for Roots). What is significant is that Mencwel himself applies the notion of "uprooting" when speaking about Brzozowski's life, e.g., "His family history is a story of uprooting," or "The student of the Niemirów gymnasium, Leopold Brzozowski, uprooted from tradition, certainly was a fine-tuned instrument of progress." $" 96$

92 Albert Thibaudet, Historia literatury francuskiej: od Rewolucji Francuskiej do lat trzydziestych XX wieku [The history of French literature: from the French Revolution to the 1930s], trans. Joanna Guze (Warszawa: Wydawnictwo Naukowe PWN, 1997), 433.

93 Louis Aragon, La lumière de Stendhal (Paris: Denoël, 1954), 266f. Cf.: "Et cela parce qu'il a été [...] un partisan : parce qu'il y a fait à la politique sa place dominante dans le monde moderne, parce qu'il y a pratiquement nié et rejeté le préjugé de la 'distance romanesque', écrit en marge de l'événement, immédiatement sur l'événement avec, pour materiel, l'événement même auquel il avait été personnellement mêlé. [...] Et $\mathrm{Le}$ Roman de l'Energie nationale [...] constitue pour la création romanesque un élément d'avant-garde, de progrès humain."

94 Boisdeffre, Métamorphose, 57, 62.

95 Andrzej Mencwel, Stanisław Brzozowski. Postawa krytyczna. Wiek XX [Stanisław Brzozowski. The critical attitude. The twentieth century] (Warszawa: Krytyka Polityczna, 2014), 197f.

96 Ibid., 654, 658. 
This explains to a certain degree why it was Les Déracinés and not any other of Barrès's works that Brzozowski was most keen to evoke, whether directly or indirectly. Already in the chapter Kryzys romantyzmu (The Crisis of Romanticism) of Legenda Młodej Polski he wrote the following words, as though forestalling future polemics, and especially the accusations that his critique of Young Poland is an echo of Barrès's novel:

Przede wszystkim chciałbym zaznaczyć swoje stanowisko względem pewnego zestawienia, które nasuwa się samo przez się. Déracinés Barrèsa są mi dobrze znani. Wiem, że niejednemu z czytelników nawinie się to przypomnienie, gdy czytać będzie o [...] samotnej jednostce. Nie będę walczył przeciwko samemu terminowi. Tak jest, ruch Młodej Polski był usiłowaniem znalezienia gruntu pod nogami, wrośnięcia w żywą sprawę, zlania się $\mathrm{z}$ nią, zapuszczenia korzeni w istotny czarnoziem ${ }^{97}$.

Foremostly, I would like to state my position with regard to a comparison that comes readily to mind. Barrès's Déracinés are by no means unknown to me. I am aware that not a few readers will naively make this association when reading about $[\ldots]$ the lonely individual. I won't struggle against the term itself. Yes, the movement Young Poland sought to find a basis to stand on, to meld with something vital, to sink roots into authentic black earth.

In Barrès's writing, the antinomy uprooted-rootedness had an ethical, and at the same time nationalistic character. After all, it is possible to take root only in something that is both national and local, provincial: in the "native ground" (today we would perhaps phrase it as the "mała ojczyzna"- "little homeland"). This is a desirable state, synonymous with moral health, but also-what was especially important for Barrès - enabling the development of personal individuality. Hence, the individual self has, or rather should have, its "roots" in its native land. However, the self is not "a greenhouse plant," but "a tree growing deep into native ground," that is, as Jacek Bartyzel clarifies, "into its nation and homeland." 98

Speaking about rootedness, the French writer evokes an organic, or, to be more precise, dendrological metaphor, where the tree is a symbol of the relationship binding the invidual and the nation; it represents the perfect society. As Thibaudet noted, "In his rich and complex work, Barrès employs an image, perhaps banal, yet completely refreshed, of a growing tree, which draws everything from its native soil: reflection, patience, logic, inner relations among

97 Brzozowski, Legenda Młodej Polski, 30.

98 Bartyzel, "Umierać, ale powoli!", 467. 
seemingly contradictory and inimical forms of life." ${ }^{.99}$ In Les Déracinés, this is illustrated by the beautiful parable about a plane tree, told to Roemerspacher by Hippolyte Taine. ${ }^{100}$ For him, the tree is an image, i.e., "une belle existence," "l'éternelle unité" and "l'éternelle énigme qui se manifeste dans chaque forme." He calls it "une fédération bruissante," and underscores that,

Cette masse puissante de verdure obéit à une raison secrète, à la plus sublime philosophie, qui est l'acceptation des necessités de la vie. Sans se renier, sans s'abandonner, il a tiré des conditions fournies par la réalité le meilleur parti, le plus utile. Depuis les plus grandes branches jusqu'aux plus petites radicelles, tout entier il a opéré le même mouvement... ${ }^{101}$

From this perspective, the nation is a tree, and the individual a leaf, i.e., a part of a larger whole, a transient part, fed by the roots of the tree. Tearing away from these roots, or being torn away from them, individuals doom themselves to weakness, and then defeat, fall, decadence. ${ }^{102}$ This is why, as Jean-Michel Wittman notes, Barrès associates the term "uprooted" with "decapitated" (décapité), with images of a body with a severed head, a body left to itself, disintegrated, doomed to degradation and wasting away. ${ }^{103}$

This is illustrated by Barrès's story of the young citizens of Lorraine "ripped out of the native ground." Their uprooting is the result of several factors, a crucial one being the educational system, as embodied by Professor Bouteiller. Bouteiller is a follower of Kant, whose philosophy was highly important for Brzozowski. In the words of the narrator of Les Déracinés, Bouteiller "[...] allait hausser ces enfants admiratifs au-dessus des passions de leur race, jusqu'à la raison, jusqu'à l'humanité."104 The Professor believes that "Le monde n'est qu'une cire à laquelle notre esprit comme un cachet impose son empreinte...,"105 and he does not want to adapt his teaching system to the character and intellec-

99 Thibaudet, Historia literatury francuskiej, 432.

100 Barrès, Les Déracinés, $193 \mathrm{f}$.

101 Ibid., 194.

102 Soucy, Fascism in France, 203. See also: „Je suis une des feuilles éphémères, que, par milliards, sur les Vosges, chaque automne pourrit et, dans cette brève minute, où l'arbre de vie me soutient contre l'effort de vents et des pluies, je me connais comme un effet de toutes les saisons qui moururent." Maurice Barrès, Les Bastions de l'Est. Au service de l'Allemagne (Paris: Félix Juven, 1906), $100 \mathrm{f}$.

103 Wittman, Barrès romancier, 93f.

104 Barrès, Les Déracinés, 18.

105 Ibid., 19. 
tual make-up of his students. The narrator of Barrès's novel describes this in the following way:

Déraciner ces enfants, les détacher du sol et du groupe social où tout les relie, pour les placer hors de leurs préjugés dans la raison abstraite, comment cela le gênerait-il, lui qui n'a pas de sol, ni de société, ni, pense-t-il, de prejugés? [...] Ses moeurs, ses attaches, il les a discutées, préférées et decidées. ${ }^{106}$

As a result, an "uprooted" individual is born, compared to a colourful balloon, aimless, dependent on external forces: "Ces lycéens frémissants dans sa main, on peut les comparer à ces ballons captifs de couleurs éclatantes et variées, que le marchand par un fil léger retient, mais qui aspirent à s'envoler, à s'élever, à se disperser sans but."107

Commenting on Bouteiller's activity, the narrator notes:

Ses élèves $[\ldots]$ ne comprennent guère que la race de leur pays existe, que la terre de leur pays est une réalité et que, plus existant, plus réel encore que la terre ou la race, l'esprit de chaque petite patrie est pour ses fils instrument d'éducation et de vie. [...] On met le désordre dans notre pays par des importations de verités exotiques, quand il'y a pour nous de vérités utiles que tirées de notre fonds. ${ }^{108}$

He also adds:

Mais précisément, un bon administrateur cherche à attacher l'animal au rocher qui lui convient; il lui propose d'abord une raison suffisante de demeurer dans sa tradition et dans son milieu; il le met ensuite, s'il y a lieu, dans une telle situation qu'il ait plaisir à s'agréger dans un groupe et que par son intérêt propre se soumette à la collectivité. ${ }^{109}$

The question is whether this was the kind of "uprooting" that Brzozowski had in mind when in Legenda Młodej Polski he wrote of Romanticism as "the revolt of the flower against its roots" (buncie kwiatu przeciw swym korzeniom)? ${ }^{110}$ Here,

106 Ibid., 24f.

107 Ibid., 38.

108 Ibid., 37.

109 Ibid., 36.

110 Brzozowski, Legenda Młodej Polski, 32. According to Mencwel, Brzozowki borrowed this expression from Nikolai K. Mikhailovskii. See: Mencwel, Brzozowski, 185. 
the dendrological metaphor-Barrès would have probably spoken of a revolt of leaves against the tree/roots - is replaced by a botanical one, while pathos, it seems, evolves towards irony. The intention, however, appears to be similar: both Brzozowski and Barrès point out the social loneliness of individuals, resulting from their conscious or unconscious tearing away from their "roots" or "ground." The writers also share a very critical view of this phenomenon. The difference lies in the fact that for Brzozowski "soil" does not necessarily need to have national connotations; he speaks rather about rootedness in the "historical soil" (glebie dziejowej), and even about "labor putting down roots ever more deeply" (coraz głębiej zapuszczającej korzenie - pracy). ${ }^{111}$

The root metaphor returns in Brzozowski's unfinished novel Dębina, whose first book bears the title Gatęzie i korzenie (Branches and Roots). But is it possible that as he wrote it Brzozowski drew inspiration from Les Déracinés? This is difficult to ascertain today, although the story of the Ogieński family, as sketched in Brzozowski's novel, could be interpreted in terms of the protagonists' "déracinement," at least in the manner employed by Konstanty Troczyński with reference to Wacław Berent's Próchno (Rotten Wood). ${ }^{112}$

111 See: "Dusze jednostkowe tkwią korzeniami swej psychiki w jednej i tej samej dziejowej glebie. Glebę tę odnajdziemy we wszystkim, co jest w danej epoce głębokie, a więc silnie i samoistnie żyje”; "[...] Polak nie wie jeszcze, w swej świadomej myśli, jak twardo już umie walczyć ze światem: - pora już tylko, by to twarde, silne życiowe jądro przedarło powłokę niedojrzałości myślowej, aby świadomość zbiorowa przestała się wyrażać w formach marnotrawiących, osłabiających wyniki bezwiednego życiowego procesu, pora, by jako jedyna ukazała się samej sobie Polska zawziętej, zapamiętałej woli życia i niestrudzonej, niesłabnącej pod ciosami, przeciwnie, wciąż krzepnącej i coraz głębiej zapuszczającej korzenie - pracy" (The psyches of individual souls are rooted in one and the same historical soil. We will find this soil in everything that is profound in a given epoch, that lives forcefully and self-sufficiently; $[\ldots]$ the Pole does not yet know, as he thinks, how tough-minded he is already in his struggle with the world - it is time, though, that this tough-minded, forceful vital core tore away the surface layer of immature thinking, in order that the collective consciousness cease to express itself in petty forms that weaken the results of the mindless vital process; it is time that Poland becomes one, shows itself as a committed, fully cognizant, wilful vitality - as labor that is tireless, undaunted by blows, that takes form and sinks roots ever more deeply). Brzozowski, Legenda Młodej Polski, 344, 122.

112 Konstanty Troczyński, "Artysta i dzieło. Studium o Próchnie Wacława Berenta" [Artist and work. A study about Próchno by Wacław Berent], in Pisma wybrane. Tom I: Studia i szkice z nauki o literaturze, ed. Stanisław Dąbrowski (Kraków: Wy- 
A separate problem is the poetics of Les Déracinés, a modern political novel, as Aragon had it, but also - quite simply - a thesis novel, whose protagonists, and readers together with them, are students, constantly educating themselves and the educated. ${ }^{113}$ As Skiwski accurately observed, "A characteristic feature of Barrès's novel is [also] a certain abstractness. The author is not trying to achieve realistic effects - he always treats external situations as opportunities to express an abstraction." "Such is the case with Les Déracinés, whose "modernity" consists in saturating the plot with "the authentic."115 This was also noted by Jabłonowski in his introduction to the Polish edition of Barrès's book:

History and fiction combine here; invention melts away in the didactic, journalistic element; poetry, artistry are bent to serve real aims, vital issues, which the author considers or sheds light on in long, animated discussions. ${ }^{116}$

Jan Lorentowicz, in turn, pointed out the characteristics of Le roman de l'énergie nationale: the foregrounding of the narrator, who intrudes in the protagonists' actions, "pushes them to the background," and who "himself speaks, explaining things, preaching political and social sermons, or expressing thoughts inspired by the observation of his own protagonists," "117 so that the novel lacks compositional unity. "We have here," the critic notes, "a historical treatise, and alongside it - a course in philosophy, a study in aesthetics, and finally several moments of a Stendhalian romance," and all this put together constitutes "an attempt at applying metaphysics to social or individual life."

Again, what remains open to consideration and discussion is the extent to which these aspects of the poetics of Les Déracinés could have not only interested Brzozowski, but also inspired his novels, in particular the works written

dawnictwo Literackie, 1997), 436f. Phrases such as "uprooted soul" or "people already completely ripped out "of native soil"” were used with reference to Brzozowski's novel by Tomasz Burek in his sketch "Arcydzieło niedokończone” (An Unfinished Masterpiece). See: Burek, Dalej aktualne, 68f.

113 Wittmann, Barrès romancier, 95.

114 Skiwski, Maurice Barrès, 103.

115 Starting with the second volume of Le roman de l'énergie nationale, Barrès's novels become less and less "novelistic": fiction is abandoned for the sake of documentary, chronicle, and testimony; see: Wittman, Barrès romancier, 121.

116 Jabłonowski, Introduction, viii.

117 Lorentowicz, "Maurycy Barrès," 253.

118 Ibid., 257. 
towards the end of his life: Dębina and Książka o starej kobiecie (A Book about an Old Woman).

\section{Towards Catholicism}

Brzozowski died in 1911 at the age of thirty-two, Barrès in 1923 at sixty-one. The author of Glosy wśród nocy could not read the works the Frenchman wrote in the last decade of his life. We cannot tell whether Brzozowski would have taken an interest in them or what he might have thought of them.

It is worth noting, however, that those later works of Barrès', from the novel La colline inspirée (1913; published in English as The Sacred Hill in 1929) onwards, signalled his turn towards Catholicism, personalism, and universalism, and eventually his "conversion," to a large extent conditioned by Henri Brémond and the works of Pascal and Newman. ${ }^{119}$ I mention this because, as we know, Brzozowski's evolution took a very similar course. For both thinkers, ultimately, the milieu of modern nationalism, whether conservative or imperialist, proved to be too restrictive.

Translated by Zofia Ziemann

\section{WORKS CITED}

Adam, Antoine et al. Literatura francuska, edited by Antoine Adam, Georges Lerminier, Éduard Morot-Sir. Translated by Joanna Arnold-Ejsmond et al. Vol. 2. Warszawa: PWN, 1980.

Aragon, Louis. La lumière de Stendhal. Paris: Denoël, 1954.

Baczko, Bronisław, “Absolut moralny i faktyczność istnienia (Brzozowski w kręgu antropologii Marksa).” In Wokół myśli Stanisława Brzozowskiego, edited by Andrzej Walicki and Roman Zimand, 127-178. Kraków: Wydawnictwo Literackie, 1974.

Barrès, Maurice. Le roman de l'énergie national. L'appel au soldat. Paris: Bibliothèque Charpentier, 1900.

- Wyrwani gruntu ojczystego. Translated by J. P., vol. 1-2. Warszawa: Drukarnia A. T. Jezierskiego, 1904.

119 Boisdeffre, Métamorphose, 75-81, Chiron, Maurice Barrès, 300-321; Barut, Egotyzm, 228-237. 
-. Pod pikielhaubq. Translated by Maria Rakowska. Warszawa: Drukarnia A. T. Jezierskiego, 1906.

- W ustugach Niemiec. Translated by Karol Scipio. Kraków: Spółka Wydawnicza Polska, 1908.

-. Colette Baudoche. Histoire d'une jeune fille de Metz. Paris: Librairie Félix Juven, 1909.

-. Colette Baudoche. Historia młodej dziewczyny z Metzu. Translated by Zofia Potocka. Lwów: „Słowo Polskie”, 1912.

-. W ogrodzie nad Orontem. Translated by Maria Ruszczyńska. Poznań-Paryż: Eos, 1923.

—. Les Déracinés. Paris: Nelson, s. a.

Bartyzel, Jacek. „Umierać, ale powoli!” O monarchistycznej i katolickiej kontrrewolucji w krajach romańskich 1815-2000. Kraków: Arcana, 2002.

Barut, Arkadiusz. Egotyzm, etyka, polityka. Myśl konserwatywna Maurycego Barrèsa. Kraków: Arcana, 2009.

Boisdeffre, Pierre, Métamorphose de la littérature. De Barrès à Malraux. Paris: Editions Alstatia, 1963.

Burek, Tomasz. Dalej aktualne. Warszawa: Czytelnik, 1973.

Burek, Tomasz. Introduction to Humor $i$ prawo by Stanisław Brzozowski, vxviii. Warszawa: Czytelnik, 1988.

Carroll, David. French Literary Fascism. Nationalism, Anti-Semitism, and the Ideology of Culture. Princeton: Princeton University Press, 1995.

Chiron, Yves. Barrès. Le Prince de la jeunesse. Préface de Jacques Laurent. Paris: Perrin, 1986.

Curtis, Michael. Three against the Third Republic. Sorel, Barrès, and Maurras. Princeton: Princeton University Press, 1959.

Cywiński, Bohdan. "Narodowe i ludzkie w myśli Stanisława Brzozowskiego." In Wokół myśli Stanisława Brzozowskiego, edited by Andrzej Walicki and Roman Zimand, 257-276. Kraków: Wydawnictwo Literackie, 1974.

Dybeł, Katarzyna, Barbara Marczuk, and Jan Prokop. Historia literatury francuskiej. Warszawa: PWN, 2005.

Głowiński, Michał. Ekspresja i empatia. Studia o młodopolskiej krytyce literackiej. Kraków: Wydawnictwo Literackie, 1997.

Heistein, Józef. Historia literatury francuskiej: od początków do czasów najnowszych. Wrocław: Zakład Narodowy im. Ossolińskich, 1987.

Huguenin, François. L'Action Française. Une historie intellectuelle. Paris: Perrin, 2011.

Jabłonowski, Władysław. Introduction to Wyrwani gruntu ojczystego, by Maurice Barrès, v-x. Warszawa: Drukarnia A. T. Jezierskiego, 1904. 
Janicka, Elżbieta. Sztuka czy naród? Monografia pisarska Andrzeja Trzebińskiego. Kraków: Universitas, 2006.

Kołaczkowski, Stefan. Pisma wybrane. Tom I. Portret i zarysy literackie. Edited by Stanisław Pigoń. Warszawa: Państwowy Instytut Wydawniczy, 1968.

Kozicka, Dorota, Joanna Orska, and Krzysztof Uniłowski (eds.). Stanisław Brzozowski (ko)repetycje. Vol. 1. Katowice: FA-art, 2012.

Lorentowicz, Jan. Nowa Francya literacka. Portrety $i$ wrażenia. Warszawa: Wł. Okręt, 1911.

Markiewicz, Henryk. Od Tarnowskiego do Kotta. Kraków: Universitas, 2010

Massis, Henri. Barrès et nous. Suivi d'une correspondance inédite (1906-1923). Paris: Plon, 1962.

Mencwel, Andrzej. Stanistaw Brzozowski. Postawa krytyczna. Wiek XX. Warszawa: Krytyka Polityczna, 2014.

Nowaczyński, Adolf. "Do Prusa, nie do Prousta!” Myśl Narodowa 6 (1929): 8385.

Ortwin, Ostap. Introduction to Glosy wśród nocy, v-xl.

Skiwski, Jan Emil. Poza wieszczbiarstwem i pedanteriq. Żeromski - pisarz $i$ apostot - oraz inne szkice krytyczne. Poznań: Księgarnia Akademicka Fiszer i Majewski, 1929.

Soucy, Robert. Fascism in France. The Case of Maurice Barrès. Berkeley: University of California Press, 1972.

Sternhell, Zeev. Maurice Barrès et le nationalisme français. Nouvelle edition augmentée d'un essai inédit. Paris: Fayard, 2000.

-. Les anti-Lumières. Une tradition du XVIIIe siècle à la guerre froide. Edition revue et augmentée. Paris: Fayard, 2010.

Thibaudet, Albert. Historia literatury francuskiej: od Rewolucji Francuskiej do lat trzydziestych XX wieku. Translated by Joanna Guze. Warszawa: Wydawnictwo Naukowe PWN, 1997.

Troczyński, Konstanty. Pisma wybrane. Tom I: Studia i szkic z nauki o literaturze, edited by Stanisław Dąbrowski. Kraków: Wydawnictwo Literackie, 1997.

Trzebiński, Andrzej. Aby podnieść różę. Szkice literackie i dramat, edited by Maciej Urbanowski. Warszawa: Fronda, 1999.

Vajda, Sarah. Maurice Barrès. Paris: Flammarion, 2000.

Wittmann, Jean-Michel. Barrès romancier. Une nosographie de la décadence. Paris: Honoré Champion, 2000.

Wyka, Marta. Czytanie Brzozowskiego. Kraków: Universitas, 2012. 